\title{
Two-dimensional echocardiographic assessment of common atrioventricular valves in univentricular hearts
}

\author{
JEFFREY F SMALLHORN, * GIUSEPPE TOMMASINI, † FERGUS J MACARTNEY \\ From the Department of Paediatric Cardiology, The Hospital for Sick Children, Great Ormond Street, London
}

SUMMARY Twelve patients with univentricular heart and common atrioventricular valve were identified by two-dimensional echocardiography. Seven had an ostium primum atrial septal defect and five a common atrium. The common atrioventricular valve had the appearance of a free floating anterior leaflet flanked by two lateral leaflets. The position of the rudimentary chamber in relation to the atrioventricular valve was posterior in six and anterior in two; no chamber was identified in four. Two-dimensional echocardiography provides a reliable method for the identification of common atrioventricular valve in univentricular heart.

Preoperative diagnosis of a common atrioventricular orifice is fairly straightforward on clinical, echocardiographic, and angiocardiographic grounds ${ }^{12}$ when two ventricles are present. But in a univentricular heart, unless there is an obvious pressure gradient between the two atria, it is frequently extremely difficult by conventional means to distinguish between a common atrioventricular orifice (common to both atria) and a single atrioventricular orifice (arising from one atrium, the other atrioventricular ${ }^{34}$ connection being absent). This distinction is not merely academic. Suitably selected patients with absence of the right atrioventricular connection (a single left atrioventricular orifice) benefit greatly from the Fontan operation or modifications thereof. ${ }^{56}$ This procedure is also employed in those with double inlet univentricular heart and two atrioventricular valves. ${ }^{7}$ In both of these conditions there is usually an adequate interatrial septum, whereas in the presence of a common atrioventricular valve either an ostium primum defect or common atrium exist. While this does not preclude these patients from having the Fontan procedure, a large patch is necessary to septate the atria, often resulting in a reduced right atrial volume.

Distinction between an absent connection and a

\footnotetext{
^JFS was awarded a British Heart Foundation Junior Research Fellowship to carry out this study. FJM is supported by the Vandervell and British Heart Foundations.

†Present address: Divisione di Cardiochirurgia Infantile, Ospedale Civile, Massa, Italy.

Received for publication 13 February 1981
}

common atrioventricular valve in life and before operation has hitherto been difficult by angiocardiography, but with two-dimensional echocardiography the atrioventricular junction and valves can be accurately assessed, ${ }^{8}$ as can the integrity of the interatrial and interventricular septa ${ }^{8}$ and the presence or absence of a rudimentary chamber. ${ }^{9}$ The aim of this study was to determine the reliability of this technique in detecting the presence of a common atrioventricular valve in patients with univentricular heart and the integrity of the interatrial septum.

\section{Subjects and methods}

The two-dimensional echocardiograms from 60 patients at The Hospital for Sick Children with a common atrioventricular orifice and a biventricular heart were reviewed, paying particular attention to those diagnostic features which were independent of the presence of a normally positioned ventricular septum. These specific features were then sought in all patients with an echocardiographic diagnosis of univentricular heart. As a result, 12 patients with a univentricular heart and a common atrioventricular orifice were identified.

All patients were studied using an Advanced Technology mechanical sector scanner with a 3.0 or $5 \mathrm{MHz}$ transducer. The standard views were employed as previously described by Tajik et al. ${ }^{8}$ Particular attention was paid to the assessment of the interatrial septum, the atrioventricular valve, and its subvalvular apparatus, using apical and subcostal four chamber views. 


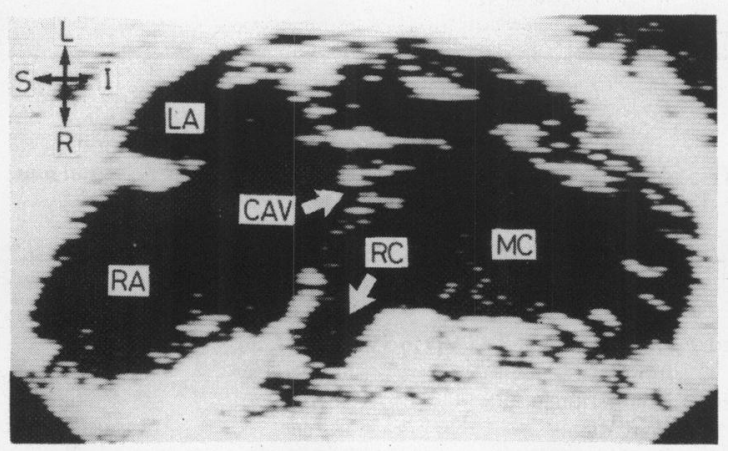

Fig. 1 Subcostal four chamber view of a child with a double inlet univentricular heart and a common atrioventricular valve. The frame is taken during systole. The trabecular septum is malaligned with the secundum atrial septum. The rudimentary chamber is anterior. CAV, common atrioventricular valve; LA, left atrium; MC, main chamber; $\mathrm{RA}$, right atrium; $\mathrm{RC}$, rudimentary chamber.

\section{Results}

Seven patients with univentricular heart had an ostium primum defect and five a common atrium (Fig. 1). The common atrioventricular valve in all patients had the same appearance as that seen in the group with biventricular hearts, that is a common free floating anterior leaflet flanked by two lateral leaflets (Fig. 2 and 3).

In all cases the tensor apparatus from the common

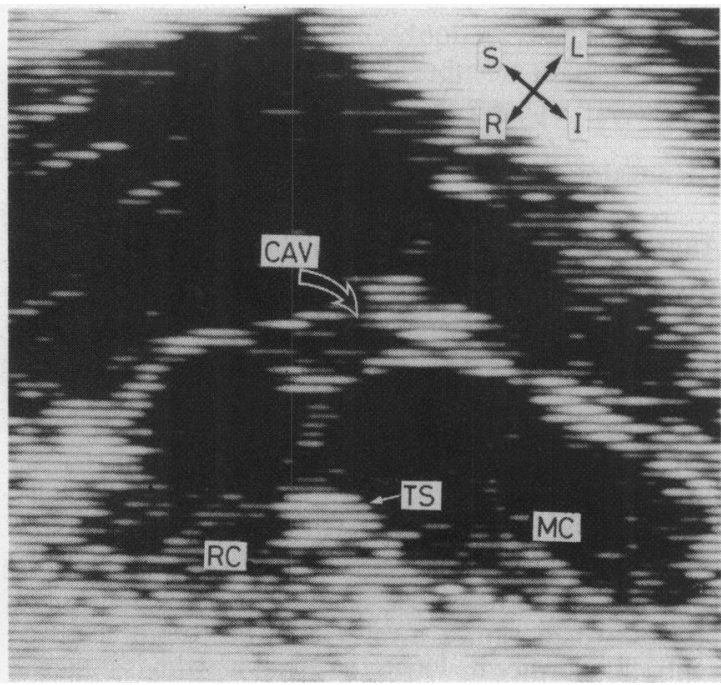

Fig. 2 Subcostal four chamber view in a patient with a double inlet univentricular heart and common atrioventricular valve. The rudimentary chamber is anterior, and some of the chordae from the common leaflet are attached to the trabecular septum. The frame is taken during systole. TS, trabecular septum (for abbreviations see Fig. 1). anterior leaflet inserted mainly into the main chamber, though in three patients there was also insertion into the rudimentary chamber (Fig. 4). Two other cases had chordae inserted into the tip of the trabecular septum (Fig. 2). Because the hearts were univentricular, this trabecular septum, separating main and rudimentary ventricular chambers when present, was displaced from its normal position and therefore not aligned with the atrial septum secundum (Fig. 4).

In one patient (case 9) necropsy disclosed the presence of a common atrioventricular valve with absence of a rudimentary chamber, thus confirming the diagnosis by echocardiography. Six cases had a trabecular septum which was posterior to the atrioventricular valve, hence the morphology of the main chamber was probably right ventricular. In two others it was anterior, these being univentricular hearts of left ventricular type. Where no trabecular septum was seen

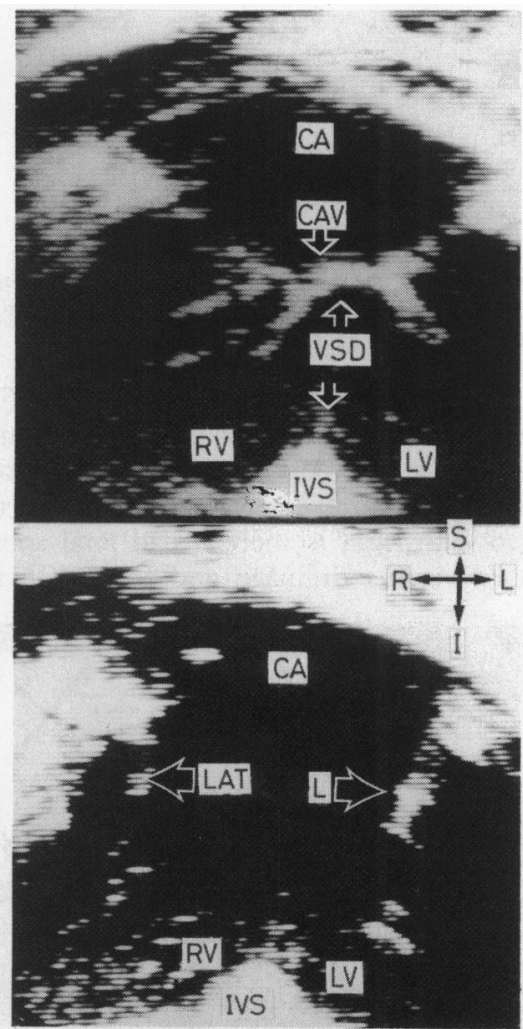

Fig. 3 Apical four chamber view in a patient with a common atrium, common atrioventricular valve, and a biventricular heart. The upper frame is taken during systole with the bucket handle appearance of the valve. The lower frame is taken during diastole, the common anterior leaflet having moved out of the transducer beam. The valve is equally committed to both chambers. CA, common atrium; IVS, interventricular septum; LAT.L, lateral leaflets; LV, left ventricle; RV, right ventricle; VSD, ventricular septal defect (for remaining abbreviations see Fig. 1). 
Table

\begin{tabular}{|c|c|c|c|c|c|c|c|c|c|}
\hline \multirow[b]{2}{*}{$\begin{array}{l}\text { Case } \\
\text { No. }\end{array}$} & \multicolumn{2}{|c|}{ Atrial defect } & \multicolumn{2}{|c|}{$\begin{array}{l}\text { Insertion of chordae } \\
\text { from anterior leaflet }\end{array}$} & \multirow[b]{2}{*}{$\begin{array}{l}\text { Position of } \\
\text { rudimentary } \\
\text { chamber }\end{array}$} & \multirow[b]{2}{*}{$\begin{array}{l}\text { Arterial } \\
\text { connections }\end{array}$} & \multirow[b]{2}{*}{$\begin{array}{l}\text { Associated } \\
\text { lesions }\end{array}$} & \multirow[b]{2}{*}{$\begin{array}{l}\text { Necropsy } \\
\text { confirmation }\end{array}$} & \multirow[b]{2}{*}{ Atrial situs } \\
\hline & $\begin{array}{l}\text { Ostium } \\
\text { primum }\end{array}$ & Common & $\begin{array}{l}\text { Main } \\
\text { chamber }\end{array}$ & $\begin{array}{l}\text { Rudimentary } \\
\text { chamber }\end{array}$ & & & & & \\
\hline 1 & Yes & - & Yes & - & Posterior & Discordant & $\begin{array}{l}\text { Interrupted } \\
\text { IVC PS }\end{array}$ & Alive & $\begin{array}{l}\text { Left } \\
\text { isomerism }\end{array}$ \\
\hline 2 & Yes & - & Yes & - & Not detected & $\begin{array}{l}\text { Double outlet } \\
\text { from MC }\end{array}$ & TAPVD to SVC & $\begin{array}{l}\text { Died, no } \\
\text { necropsy }\end{array}$ & $\begin{array}{l}\text { Right } \\
\text { isomerism }\end{array}$ \\
\hline 3 & 一 & Yes & Yes & - & Not detected & $\begin{array}{l}\text { Double outlet } \\
\text { from MC }\end{array}$ & PS & Alive & $\begin{array}{l}\text { No films } \\
\text { available }\end{array}$ \\
\hline 4 & - & Yes & Yes & - & Not detected & $\begin{array}{l}\text { Double outlet } \\
\text { from MC }\end{array}$ & - & Alive & $\begin{array}{l}\text { No films } \\
\text { available }\end{array}$ \\
\hline 5 & Yes & - & Yes & $\begin{array}{l}\text { Tip of } \\
\text { trabecular S }\end{array}$ & Anterior & Concordant & PS & Alive & Solitus \\
\hline 6 & Yes & - & Yes & Yes & Posterior & Discordant & PS & Alive & $\begin{array}{l}\text { No films } \\
\text { available }\end{array}$ \\
\hline 7 & - & Yes & Yes & - & Posterior & $\begin{array}{l}\text { Single outlet } \\
\text { aorta }\end{array}$ & PA & Alive & Solitus \\
\hline 8 & - & Yes & Yes & Yes & Posterior & $\begin{array}{l}\text { Double outlet } \\
\text { from MC }\end{array}$ & PS & Alive & Solitus \\
\hline 9 & Yes & - & Yes & - & Not detected & $\begin{array}{l}\text { Single outlet } \\
\text { from MC }\end{array}$ & $\begin{array}{l}\text { PA } \\
\text { TAPVD to SVC }\end{array}$ & Yes & $\begin{array}{l}\text { Right } \\
\text { isomerism }\end{array}$ \\
\hline 10 & Yes & - & Yes & - & Anterior & Concordant & - & Alive & Solitus \\
\hline 11 & Yes & - & Yes & - & Posterior & $\begin{array}{l}\text { Double outlet } \\
\text { from MC }\end{array}$ & PS & Alive & $\begin{array}{l}\text { Right } \\
\text { isomerism }\end{array}$ \\
\hline 12 & - & Yes & Yes & Yes & Posterior & $\begin{array}{l}\text { Double outlet } \\
\text { from MC }\end{array}$ & PS & Alive & $\begin{array}{l}\text { Right } \\
\text { isomerism }\end{array}$ \\
\hline
\end{tabular}

IVC, inferior vena cava; $M C$, main chamber; PA, pulmonary atresia; PS, pulmonary stenosis; S, septum; SVC, superior vena cava; TAPVD, total anomalous pulmonary venous drainage.

the morphology was presumed indeterminate (Table).

In those cases where atrial situs was determined by high kilovoltage filtered beam radiography, four had situs solitus, four right isomerism, and one left isomerism. Two with right isomerism had total anomalous pulmonary venous drainage and the case with left

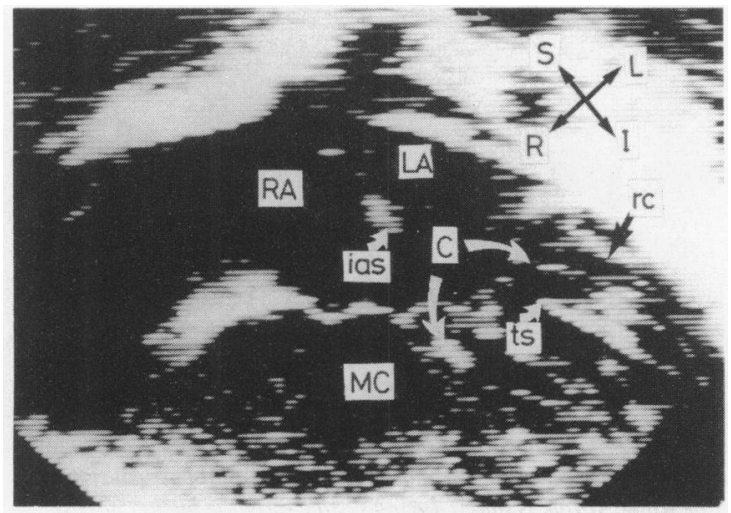

Fig. 4 Apical four chamber view in a patient with a double inlet univentricular heart and common atrioventricular valve. The rudimentary chamber which is posterior, has chordae inserting into $i t$. The tip of the trabecular septum is malaligned with the interatrial septum. C, chordae; ias, interatrial septum (for remaining abbreviations see Fig. 1 and 2). isomerism an interrupted inferior vena cava. Arterial connections were variable, with two being concordant, two discordant, six double outlet, and two single outlet from the main chamber. Seven patients had associated pulmonary stenosis and two pulmonary atresia.

\section{Discussion}

Anatomically, there are two hallmarks of a common atrioventricular valve. Normally both are present; occasionally one is missing. Firstly, the valve is common to both atria, that is to say, there is an ostium primum atrial septal defect. Secondly, the valve o normally has five leaflets, ${ }^{10} 11$ and therefore does not $N$ resemble either a mitral or a tricuspid valve. In the biventricular heart, two of these five leaflets normally bridge the ventricular septum, one anteriorly and one posteriorly. ${ }^{1011}$ These bridging leaflets are therefore common to both ventricles; their presence makes it possible to recognise a rare form of common atrioventricular orifice in which the atrial septum is intact. ${ }^{10}$ While we are not aware that the combination of univentricular heart, common atrioventricular orifice, and intact atrial septum has been described in the published reports, if it were to be, the diagnosis would have to be based upon the distinctive morphology of the valve leaflets. 
Hitherto, diagnosis in life of common atrioventricular valve with univentricular heart has depended, if there is no obvious interatrial pressure gradient, upon angiographic identification of the interatrial septum and the appearance of the valve during diastole ${ }^{34}$ But the diastolic appearance of a common valve may be indistinguishable from that of a single valve,${ }^{4}$ and failure to show the septum primum may simply be the result of its not being profiled in the projection chosen.

Single crystal echocardiography has played an important role in assessing atrioventricular valves in univentricular hearts, but the differentiation between a common and a single atrioventricular valve is again very difficult. ${ }^{12-14}$

Two dimensional echocardiography is a technique ideally suited to separating these two entities, since the interatrial septum and valve leaflets can be so reliably imaged. Furthermore, analysis of the relation of septal structures (if any) in the ventricular mass to the atrioventricular junction ${ }^{34}$ permits recognition of the univentricular heart itself.

Thus, demonstration of a single atrium or ostium primum atrial septal defect indicates the presence of an atrioventricular defect. Alleged exceptions to this rule, ${ }^{15}$ on close examination, usually have a small rim of septum primum present. By two-dimensional echocardiographic studies even small rims of primum or secundum septum can be visualised.

The common atrioventricular valve in a biventricular or univentricular heart has a characteristic appearance on two-dimensional echocardiography - that is a free floating common anterior leaflet flanked by two lateral leaflets (Fig. 2 and 3). The free floating leaflet disappears from the ultrasonic beam during diastole, returning during systole (Fig. 3), thus appearing to move in a superoinferior plane. Chordae from these leaflets are inserted into either the ventricular chambers in a biventricular heart or the main chamber, with or without rudimentary chamber insertion, in a univentricular heart. An anterior leaflet flanked by two lateral leaflets can also be seen in hearts with straddling tricuspid valve, ${ }^{16}$ but demonstration of a second atrioventricular valve in that condition easily distinguishes it from a common orifice. In the exceedingly rare condition where one valve straddles and the other is absent, ${ }^{17}$ the septum primum is intact, and should be readily identifiable.

Biventricular hearts with atrioventricular defects frequently exhibit right or left ventricular dominance $^{1819}$ (Fig. 5), that is one ventricle is hypoplastic. Distinction between extreme ventricular dominance and univentricular heart is usually straightforward at necropsy, but occasionally is subtle, particularly when the main chamber is of right morphology. The key to the anatomical distinction in such cases is recognition of a raphe separating mitral from tricuspid components

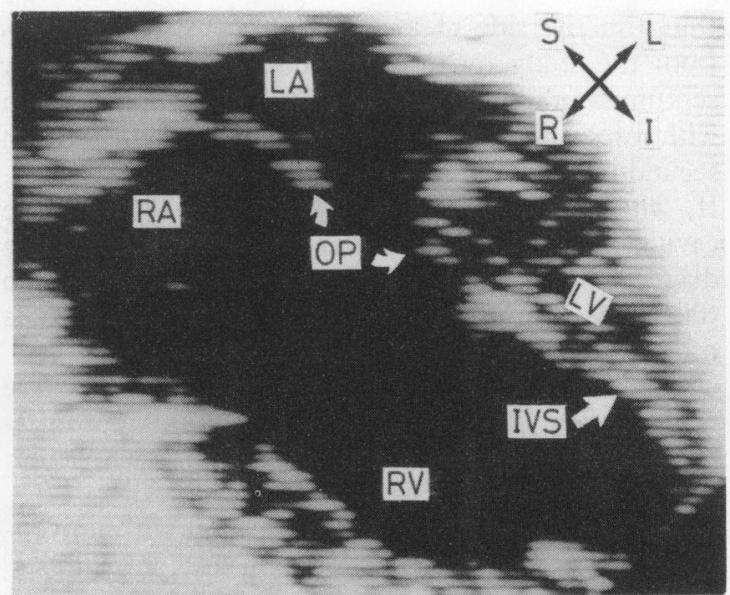

Fig. 5 Apical four chamber view in a child with a common atrioventricular valve and a biventricular heart in which the right ventricle is dominant, the left ventricle being hypoplastic. The interventricular septum is aligned with the interatrial septum. OP, ostium primum (for remaining abbreviations see Fig. 1 and 3).

when it is present. ${ }^{17}$ When such a raphe is present the two components of the common valve can be assigned to their ventricular chambers by the $50 \%$ rule; when absent, the $75 \%$ rule is applied. ${ }^{17}$ Since we have not identified such a raphe with two-dimensional echocardiography, we cannot be entirely certain as to the correct assignation of the common valve in all cases (Fig. 6). We believe, however, we have erred if any-

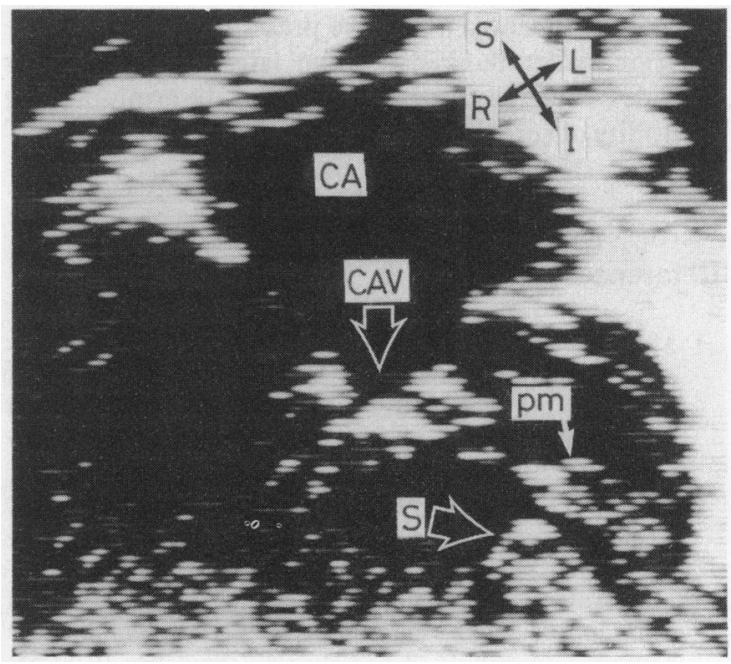

Fig. 6 Apical four chamber view in a child with a common atrium and common atrioventricular valve, which is mainly committed to the right sided chamber. The valve straddles into the other chamber and the septum separating the ventricular mass cannot be aligned with an interatrial septum as a common atrium exists. pm, papillary muscle; S, septum dividing the ventricular mass (for remaining abbreviations see Fig. 1 and 3). 
thing on the side of excluding univentricular hearts from the study by insisting that when a trabecular septum is present, that it is grossly malaligned, both with respect to the ventricular mass and to the septum secundum, when present (compare Fig. 4 and Fig. 5). If, whatever cut is employed, muscle separates the cavities of the rudimentary chamber and atria, then the diagnosis must be a univentricular heart. If no trabecular septum is seen, the same conclusion is probably valid.

Absent right or left connections should not cause confusion, as in these cases the primum septum is present, and the morphology of the atrioventricular valve can be determined echocardiographically.

Atrioventricular defects in association with univentricular heart are commonly found in situs ambiguus, ${ }^{20}$ the diagnosis of which cannot be established by echocardiography. Hence, demonstration of this combination of lesions should lead on to visualisation of the bronchi by high kilovoltage filtered beam radiography, ${ }^{21}$ if this has not already been done. Furthermore, in the case of right isomerism, total anomalous pulmonary venous return is common, so that every effort should be made to identify the pulmonary veins positively. In the case of left isomerism, a careful search should be made for interruption of the inferior vena cava.

Thus, by the use of two-dimensional echocardiography the diagnosis of a common atrioventricular valve in a univentricular heart can be readily made by demonstrating an ostium primum defect or common atrium, and by identifying the characteristic feature of the only atrioventricular valve present, which is a wide anterior leaflet flanked by two lateral leaflets. This provides valuable information when determining the feasibility of cardiac surgery in such cases.

\section{References}

1 Macartney FJ, Rees PG, Daly K, et al. Angiocardiographic appearances of atrioventricular defects with particular reference to distinction of ostium primum atrial septal defect from common atrioventricular orifice. $\mathrm{Br}$ Heart f 1979; 42: 640-56.

2 Hagler DJ, Tajik AJ, Seward JB, Mair DD, Ritter DG. Real-time wide-angle sector echocardiography: atrioventricular canal defects. Circulation 1979; 59: 140-50.

3 Macartney FJ, Partridge JB, Scott O, Deverall PB. Common or single ventricle: an angiocardiographic and hemodynamic study of 42 patients. Circulation 1976; 53: 543-54.

4 Macartney FJ, Daly K, Wilkinson JL, Anderson RH. Angiocardiography in the pre-operative evaluation of patients with univentricular hearts. Herz 1979; 2: 213-9.

5 Fontan F, Baudet E. Surgical repair of tricuspid atresia. Thorax 1971; 26: 240-8.
6 Gale AW, Danielson GK, McGoon DC, Wallace RB, Mair DD. Fontan procedure for tricuspid atresia. Circulation 1980; 62: 91-6.

7 Gale AW, Danielson GK, McGoon DC, Mair DD. Modified Fontan operation for univentricular heart and complicated congenital lesions. F Thorac Cardiovasc Surg 1979; 78: 831-8.

8 Tajik AJ, Seward JB, Hagler DJ, Mair DD, Lie JT. Two-dimensional real-time imaging of the heart and great vessels. Technique, image orientation, structure identifcation, and validation. Mayo Clin Proc 1978; 53: 271-303.

9 Gussenhoven WJ, de Villeneuve JF, Buis-Liem TN, Becker AE. Echocardiographic criteria for univentricular hearts (abstract). In: World Congress of Paediatric Cardiology Abstract Booklet. London 1980: no. 181.

10 Piccoli GP, Gerlis LM, Wilkinson JL, Lozsadi K, Macartney FJ, Anderson RH. Morphology and classification of atrioventricular defects. Br Heart $\mathcal{F}$ 1979; 42: 621-32.

11 Piccoli GP, Wilkinson JL, Macartney FJ, Gerlis LM, Anderson RH. Morphology and classification of complete atrioventricular defects. Br Hear $\mathcal{F}$ 1979; 42: 633-9.

12 Mortera C, Hunter S, Terry G, Tynan M. Echocardiography of primitive ventricle. BrHeartf 1977; 39: 847-55.

13 Bini RM, Bloom KR, Culham JAG, Freedom RM, Williams CM, Rowe RD. The reliability and practicality of single crystal echocardiography in the evaluation of single ventricle. Angiographic and pathological correlates. Circulation 1978; 57: 269-77.

14 Seward JB, Tajik AJ, Hagler DJ, Ritter DG. Contrast echocardiography in single or common ventricle. Circulation 1977; 55: 513-9.

15 Moreno F, Quero M, Diaz LP. Mitral atresia with normal aortic valve. A study of eighteen cases and a review of the literature. Circulation 1976; 53: 1004-10.

16 Smallhorn JF, Tommasini G, Macartney FJ. The detection and assessment of straddling and overriding atrioventricular valves by two-dimensional echocardiography. $\mathrm{BrHeart} \mathcal{f}$ (in press).

17 Milo S, Ho SY, Macartney FJ, et al. Straddling and overriding atrioventricular valves: morphology and classifcation. Am F Cardiol 1979; 44: 1122-34.

18 Bharati S, Lev $M$. The spectrum of common atrioventricular orifice (canal). Am Heart f 1973; 86: 553-61.

19 Freedom RM, Bini M, Rowe RD. Endocardial cushion defect and significant hypoplasia of the left ventricle: a distinct clinical and pathological entity. Eur $\mathcal{f}$ Cardiol $1978 ; 7: 263-81$.

20 Keeton BR, Macartney FJ, Hunter S, et al. Univentricular heart of right ventricular type with double or common inlet. Circulation 1979; 59: 403-11.

21 Deanfield JE, Leanage R, Stroobant J, Chrispin AR, Taylor JFN, Macartney FJ. Use of high kilovoltage filtered beam radiographs for detection of bronchial situs in infants and young children. Br Heart $\mathcal{F}$ 1980; 44: $577-83$.

Requests for reprints to Professor F J Macartney, The Hospital for Sick Children, Great Ormond Street, London WC1N 3JH. 